\title{
Elisheva Baumgarten and Judah D. Galinsky, Eds. Jews and Christians in Thirteenth-Century France
} (New York: Palgrave Macmillan, 2015) xxv + 282 pp.

\author{
HARVEY J. HAMES \\ hames@exchange.bgu.ac.il \\ Ben-Gurion University of the Negev, Beer-Sheva 8410501 Israel
}

Centuries are a convenient way of defining time. When teaching history, we define our periods in terms of centuries, as that allows us to make general statements with greater ease. The problem is that when we start going into more detail, the concept of "the history of centuries" becomes problematic. A pertinent example of this is what is referred to as the "twelfth-century renaissance," which is anything but confined to the years 1100-1199. The co-editors of this stimulating collection of papers, based on presentations at a conference in Jerusalem, are well aware of this, stating from the outset that they are talking about "a long thirteenth century, broadly defined" (p. 1). Rather than framing the subject in this way, the term "late medieval" would have been more suitable, allowing greater flexibility.

The geographic designation in the title of this book is also tricky. What constitutes France in the thirteenth century? Is thirteenth century France, if it can be said to exist, the same for the Jews and Christians of the title? Again, Baumgarten and Galinsky are aware of this problem and address it in the introduction, particularly with regard to the tendency to lump together the Jews of Ashkenaz (Germany and France). Yet, what is not addressed is the considerable expansion of the French kingdom to include almost the whole of Languedoc following the agreement of Paris in 1229. This, slowly but surely, brought the Jews of southern France into the ambit of the French monarchy with important consequences.

The book contains sixteen articles divided according to three themes: "Learning, Law, and Society," "Polemics, Persecutions, and Mutual Perceptions," and "Cultural Expressions and Appropriations: Art, Poetry, and Literature." They were written by a broad range of scholars, some very well known, others who will soon be. Some of the topics addressed include biblical exegesis (Lesley Smith, Susan Einbinder, Ari Geiger), devotion (Margo Stroumsa-Uzan, Rella Kushelevsky), law and legal issues (Karl Shoemaker, Judah Galinsky, Ephraim Kanarfogel, John Tolan), polemics (Daniel Lasker, David Berger, Yossef Schwartz), gender (Anne E. Lester), conversion (Jessica Marin Elliott), languages 
(Cyril Aslanov), and art (Sara Offenberg). Many of the articles engage with more than one of the aforementioned topics.

The introduction, written jointly by the editors, does a very nice job of summarizing the articles, so, due to a lack of space, I will focus briefly on two articles which particularly caught my eye.

Jessica Marin Elliott, in “Jews 'Feigning Devotion': Christian Representations of Converted Jews in French Chronicles before and after the Expulsion of 1306," looks at a variety of Christian chronicles written in France and the lowlands in the late thirteenth and fourteenth centuries dealing with Jewish converts. She shows that in the later chronicles, there is considerable doubt whether Jewish conversion to Christianity is ever sincere. Focusing on stories dealing with host desecration and on insincere conversions designed to allow the convert to gain access to and then to destroy Christian images (mainly of the Virgin Mary), she shows how true conversion becomes an impossibility. Referencing David Nirenberg's studies on the aftermath of the events of 1391 in the Iberian Peninsula, she suggests that this reflects a crisis of identity in France in the early fourteenth century. This analysis fits in extremely well with what happens in England leading up to the expulsion of the Jews in 1290, a topic I have written about. The tale of Adam of Bristol, an invented ritual murder including the intervention of the Virgin Mary, becomes a story of exclusion whereby the Jews cannot convert and become part of the Christian commonwealth.

Sara Offenberg is forging a path as a fascinating scholar who is able to connect text, illustration, and context in manuscripts. In "Mirroring Samson the Martyr: Reflections of Jewish-Christian Relations in the North French Hebrew Illuminated Miscellany," she focuses on a prayer miscellany from northern France, circa 1280, containing some 84 different texts. It includes a poem about Samson of Metz, who converted to Christianity in prison, but reverted to Judaism and died as a martyr. This poem intersects with an illustration of the biblical Samson and a lion which uses Christian iconography and raises the possibility of connections between Jewish and Christian scribes and artists. The brevity of the article limits her elaboration of the central themes and the reader will be left wishing for a more detailed exposition of the connections between text and illustration.

While most of the articles are within the remit of the collection's title, Tolan's interesting article, "Of Milk and Blood: Innocent III and the Jews, Revisited" is a little out of place. It does not really address Jewish-Christian interaction in France. Rather, it refers more generically to papal law regarding Jews' use of Christian wet nurses.

This volume brings new and welcome perspectives on Jewish-Christian relations in a period which is generally seen to have witnessed deterioration in the latter's attitude toward the former. These relations are more complex and engaged and on far more levels and in more areas than previously conceived. The studies gathered in this fascinating volume suggest that there is still much more work to be done. 